\title{
Meningkatkan Kemampuan Mengenal Bentuk Geometri melalui Permainan Cacaburange
}

\author{
Ayu Fajarwati, Wulan \\ ${ }^{1.2}$ Pendidikan Guru Pendidikan Anak usia Dini STKIP Setia Budhi Banten \\ E-mail: wulan@gmail.com
}

\begin{abstract}
ABSTRAK
Tujuan dari penelitian ini adalah untuk meningkatkan kemampuan geometri melalui game cacaburange. Metode yang digunakan adalah penelitian tindakan melalui dua siklus, siklus terdiri dari perencanaan, tindakan, pengamatan, dan refleksi. Subjek penelitian adalah anak usia 4-5 tahun di TK Setiabudhi yang memiliki masalah kemampuan geometri sebanyak 10 orang. Pengumpulan data menggunakan lembar observasi, catatan lapangan, dan dokumentasi rekaman. Analisis persentase data yang digunakan dalam penelitian ini berdasarkan Mills sebesar $71 \%$, hasil akhir analisis keseluruhan adalah $84,66 \%$ dengan peningkatan $46,11 \%$. Berdasarkan peningkatan persentase penelitian saat ini, dapat dinyatakan bahwa hipotesis diterima. Dapat disimpulkan bahwa penggunaan game cacaburange dapat meningkatkan kemampuan geometri pada anak usia 4-5 tahun. Implikasi dari penelitian ini bahwa game cacaburange dapat digunakan sebagai alternatif untuk meningkatkan kemampuan geometri. Peningkatan kemampuan geometri pada anak-anak dapat membantu kemampuan anak untuk memahami dan mengenali geometri.
\end{abstract}

Kata kunci: geometri; cacaburange; matematika

\begin{abstract}
The Purpose of this research is to improve ability of geometry through cacaburange game. The method used is action research through two cycles, the cycles consist of planning, acting, observing, and reflecting. Subjects were children ages 4-5 years at TK Setiabudhi who had problems in ability of geometry as many as 10 people. Data collecting using observation sheets, field notes, and record documentation. Analysis of the percentage of data used in this study based on Mills in the amount of $71 \%$, the end result of overall analysis is $84,66 \%$ with increased $46,11 \%$. Based on the increasing percentage of the current study, it can be stated that the hypothesis is accepted. It can be concluded that the use of cacaburange games can improve ability of geometry on children ages 4-5 years. The implications of this research that the cacaburange games can be used as an alternative to improve the ability of geometry. Increased ability of geometry in children can help with the child's ability to understand and recognize geometry.
\end{abstract}

Key words: geometry; cacaburange; mathematics

(C)2019 Ayu Fajarwati, Wulan Under The License CC- BY SA 4.0

\section{PENDAHULUAN}

Anak usia dini adalah sekelompok anak yang berada dalam proses pertumbuhan dan perkembangan yang unik.Pertumbuhan dan perkembangan anak usia dini perlu diarahkan pada peletakan dasar-dasar yang tepat bagi pertumbuhan dan perkembangan manusia seutuhnya. Hal ini meliputi pertumbuhan dan perkembangan fisik, daya fikir, daya cipta, 


\section{PEDAGOGIKA}

\section{Volume 10 (Nomor 2) 2019}

\section{Hal. 95-100}

sosial emosional, bahasa dan komunikasi yang seimbang bagi dasar pembentukan pribadi yang utuh, agar anak dapat tumbuh dan berkembang secara optimal (Mansur, 2011). Pertumbuhan dan perkembangan pada anak harus distimulasi dengan baik, agar tugas perkembangannya dapat berkembang secara optimal. Salah satu tugas yang harus di stimulasi adalah perkembangan kognitif dengan mengenalkan benda-benda yang ada di sekitar anak.

(Lestari, 2011) menjelaskan bahwa mengenalkan bentuk geometri pada anak usia dini adalah kemampuan anak mengenal, menunjuk, menyebutkan, serta mengumpulkan benda-benda di sekitar berdasarkan bentuk geometri. Mengenalkan bentuk-bentuk geometri pada anak usia dini dimulai dari membangun konsep yaitu dengan mengidentifikasi ciri-ciri bentuk geometri. (Eliyawati, 2005) mencirikan karakteristik anak usia dini yaitu dengan daya perhatian yang pendek, sehingga untuk menarik perhatian dan membantu anak dalam mengenal bentuk-bentuk geometri perlu dikenalkan dengan cara bermain yang dapat dilakukan dengan bentuk-bentuk geometri melalui permainan tradisional, kecuali terhadap hal-hal yang secara intrinsik menarik dan menyenangkan, karena anak sangat sulit untuk memperhatikan sesuatu dalam jangka waktu yang lama. Menurut (Sujiono:2006) bidang pengembangan kognitif meliputi pengembangan auditory, visual, taktil, kinestetik, aritmetika, geometri, dan sains permulaan. Sesuai dengan pendapat tersebut maka dalam penelitian ini permainancacaburange hanya dibatasi pada bentuk-bentuk geometri. Alasan digunakan geometri karena geometri berkaitan dengan kemampuan mengembangkan konsep bentuk dan ukuran.

Hasil observasi pada anak usia 4-5 tahun di TK Setia Budhi Rangkasbitung, bahwa dari 15 anak didik ada 10 anak yang masih kurang dalam kemampuan mengenal bentuk geometri. Hal ini juga diungkapkan oleh guru kelas mengenai kurangnya kemampuan membedakan bentuk geometri serta menyebutkan nama dari bentuk geometri tersebut. Guru lebih banyak menggunakan metode bercakap-cakap pada anak serta media yang digunakanpun hanya terbuat dari kardus yang dipotong kecilkecil. Salah satu permainan yang dapat dikenalkan pada anak dalam meningkatkan kemampuan geometri yaitu dengan permainan cacaburange, dimana pada permainan cacaburange anak diminta untukduduk melingkar dan masing-masing anak memegang kepingan bentuk geometri. Bentuk geometri ini kemudian dipindahkan dari satu anak ke anak lainnya sambil diiringi lagu cacaburange, dan anak lainnya yang jaga akan menebak bentuk geometri tersebut. Hal ini dipilih karena kegiatan bermain dinilai sangat tepat dan efektif untuk diterapkan pada anak usia dini. Permainan tradisional dapat menjadi salah satu alternatif permainan menyenangkan yang dapat meningkatkan kemampuan dalam mengenal bentuk geometri. Permainan cacaburangeini akan diperkenalkan terlebih dahulu pada anak.

Peneliti tertarik untuk melakukan penelitian tindakan mengenai penggunaan permainan cacaburange dalam mengatasi permasalahan rendahnya kemampuan geometri pada anak usia 4-5 tahun di TK Setia budhi Rangkasbitung. 


\section{PEDAGOGIKA}

\section{Volume 10 (Nomor 2) 2019}

Hal. 95-100

(Lestari, 2011) menjelaskan bahwa mengenal bentuk geometri pada anak usia dini adalah kemampuan anak mengenal, menunjuk, menyebutkan serta mengumpulkan benda-benda yang ada dilingkungan sekitar berdasarkan bentuk geometri. (Triharso, 2013), menyatakan bahwa dalam membangun konsep geometri pada anak dimulai dari mengidentifikasi bentuk-bentuk, menyelidiki bangunan dan memisahkan gambar-gambar biasa seperti, segi empat, lingkaran, dan segi tiga. (Tarigan, 2006), menjelaskan bahwa geometri adalah berpikir matematis, yaitu meletakan struktur hirarki dari konsepkonsep lebih tinggi yang terbentuk berdasarkan apa yang telah terbentuk sebelumnya, sehingga dalam belajar geometri seseorang harus mampu menciptakan kembali semua konsep yang ada dalam pikirannya. Mengenal kan bentuk-bentuk geometri pada anak usia dini dapat dilakukan dengan cara mengajak anak untuk bermainsambil mengamati gambar yang ada disekelilingnya. Tahap belajar geometri pada anak, diantaranya adalah: (1) Tahap pengenalan, (2) tahap analisis, (3) tahap pengurutan, (4) tahap deduksi, (5) tahap akurasi. Pada tahap pengenalan anak mulai belajar mengenal suatu bentuk geometri secara keseluruhan, namun pada tahap ini anak belum mengetahui adanya sifat-sifat dari bentuk geometri. selanjutnya pada tahap analisis pada tahap ini anak mulai mengenali sifat-sifat yang dimiliki benda geometri yang diamati. bahkan pada tahap ini anak sudah mampu menyebutkan aturan yang terdapat pada benda geometri tersebut. Tahap pengurutan pada tahap ini anak sudah mampu melakukan penarikan kesimpulan, berpikir deduktif, namun kemampuan ini belum berkembang secara penuh. Tahap deduksi anak sudah mampu menarik kesimpulan secara deduktif, yaitu penarikan kesimpulan dari hal-hal yang bersifat umum menuju hal-hal yang bersifat khusus. Tahap terakhir yaitu tahap akurasi anak mulai menyadari betapa pentingnya ketepatan dari prinsip-prinsip dasar yang melandasi suatu pembuktian.Dari beberapa paparan diatas dapat ditarik kesimpulan bahwa kemampuan mengenal bentuk geometri adalah kemampuan berpikir secara sistematis anak dalam mengenal, menunjuk, menyebutkan benda-benda yang berbentuk geometri sesuai dengan apa yang ada disekitar lingkungannya, melalui tahapantahapannya.

$$
\text { Piaget (dalam Mayesty }
$$
mengatakan bahwa bermain adalah suatu kegiatan yang dilakukan berulang-ulang dan menimbulkan kesenangan/kepuasan bagi diri seseorang. Dockett dan Fleer (dalam Sujiono, 2009) berpendapat bahwa bermain merupakan kebutuhan bagi anak, karena melalui bermain anak akan memperoleh pengetahuan yang dapat mengembangkan kemampuan dirinya. Bermain merupakan suatu aktivitas lain seperti belajar dan bekerja yang selalu dilakukan dalam rangka mencapai suatu hasil akhir. Cacaburange merupakan lagu permainan sunda yang tujuannya untuk menebak suatu benda seperti pacublak-cublak uang dan tungtung kalintungan (Hidayat, 2005). Permainan cacaburange sekarang ini dalam dunia permainan anak-anak merupakan permainan yang sudah langka dimainkan. Permainan anak-anak yang lebih moderen banyak tersaji disekitar anak pada masa sekarang ini. Keberadaan permainan cacaburange pada saat ini susah ditemukan. Permainan 


\section{PEDAGOGIKA}

\section{Volume 10 (Nomor 2) 2019}

Hal. 95-100

cacaburange dilihat dari segi edukasi merupakan permainan yang memiliki nilainilai pendidikan yang tinggi. Banyak hal yang bisa didapatkan dalam bermain cacaburange. Pengetahuan didapatkan dalam permainan ini dari muatan-muatan gambaran atau aktivitas yang ada. Nilainilai yang didapatkan dalam permainan ini adalah nilai suportivitas, kejujuran, kebersamaan, toleransi, ketelitian, kedisiplinan, dan sebagainya. Cara memainkan permainan cacaburange menurut (Hidayat, 2005) adalah sebagai berikut: (1) anak-anak berkumpul dan salah seorang anak membungkuk yang akan menebak barang atau benda yang dipegang anak yang lainnya, (2) anak-anak yang lain menyimpan tangannya sambil dikepalkan, salah sorang anak memegang benda yang akan ditebak. Ketika bernyanyi, anak yang membungkuk bangun, dan menebak benda yang akan ditebak. Ketika bernyanyi, anak yang membungkuk bangun dan menebak benda tadi, jika tebakannya benar ada di salah seorang anak misalnya nama anak yang memegang benda itu Dani, Maka Dani lah yang mendapat giliran harus membungkuk.

\section{METODE PENELITIAN}

Penelitian dilakukan di TK Setia budhi Rangkasbitung. Dengan fokus penelitian pada anak usia 4-5 tahun yang berjumlah 10 orang. Waktu penelitian direncanakan yaitu Juli hingga Agustus tahun ajaran 2018/2019.Jenis penelitian yang dilakukan adalah penelitian tindakan kelas (action research). (Arikunto, 2007) berpendapat bahwa penelitian tindakan kelas melalui paparan gabungan definisi dari kata "penelitian, tindakan, dan kelas". Penelitian adalah kegiatan mencermati suatu objek dengan menggunakan aturan metodologi tertentu untuk memperoleh data atau informasi yang bermanfaat untuk meningkatkan mutu suatu hal menarik minat dan penting bagi peneliti. (Suhardjono, 2007) juga mengungkapkan bahwa penelitian kelas adalah penelitian tindakan yang dilakukan dikelas dengan tujuan memperbaiki/meningkatkan mutu praktik pembelajaran. Jenis penelitian yang dilakukan adalah penelitian tindakan dengan model Kemmis dan Taggart yang meliputi perencanaan, tindakan, pengamatan, dan refleksi.

\section{HASIL PENELITIAN DAN PEMBAHASAN}

Data pra-penelitian diperoleh data sebanyak 10 orang anak sebesar 38,55\% yang dinyatakan belum mencapai target, dengan dengan nilai terendah yang diperoleh responden sebesar 7 dengan presentase $33,3 \%$ dan nilai tertinggi yang diperoleh responden sebesar 11 dengan presentase 52,38\%.Berdasarkan hasil observasi pra-penelitian menunjukan bahwa kemampuan anak dalam mengenal bentuk geometri masih terbilang rendah, hal ini terlihat pada saat anak menyebutkan, mengelompokan, dan menyusun bentuk geometri, anak-anak belum dapat melakukannya Kemampuan anak dalam mengenal bentuk geometri masih dibawah rata-rata.

Setelah dilakukan berbagai kegiatan pada siklus I dan siklus II, diperoleh hasil penelitian meningkatkan kemampuan mengenal bentuk geometri melalui permainan cacaburange berhasil meningkat dari sebelum tindakan sebesar 38,55\% menjadi sebesar $55,70 \%$ di siklus I dan mengalami peningkatan lagi menjadi 


\section{PEDAGOGIKA}

\section{Volume 10 (Nomor 2) 2019}

Hal. 95-100

$84,66 \%$ di siklus II. Kemampuan mengenal bentuk geometri pada anak mengalami peningkatan karena adanya proses perbaikan kualitas pembelajaran, interaksi guru dan peserta didik juga ditingkatkan.Peningkatan kemampuan mengenal bentuk geometri ini sudah sesuai dengan kriteria keberhasilan yang telah disepakati oleh peneliti bersama kolabolator yaitu sebesar $71 \%$.

Berdasarkan hasil analisis data dengan melihat persentase peningkatan kemampuan mengenal bentuk geometri pada pra-penelitian dan akhir siklus I yaitu $38,55 \%$ dan $55,70 \%$ dan persentase peningkatan mengenal bentuk geometri pada siklus II 84,66\%. Hasil tersebut menunjukan bahwa pada siklus I hasil peningkatan yang diharapkan belum signifkan, kemudian setelah dilanjutkan dengan siklus II, maka hasil peningkatan kemampuan mengenal bentuk geometri mengalami peningkatan sesuai dengan yang diharapkan. Hasil tersebut menunjukan kesesuaian dengan hipotesis tindakan yaitu terjadi persentase kenaikan sebesar 28,96\% maka hipotesis diterima. Dengan demikian dapat dikatakan bahwa melalui permainan cacaburange dapat meningkatkan kemampuan anak dalam mengenal bentuk geometri.

Hasil data kualitatif membuktikan bahwa pemberian kegiatan bermain cacaburange dapat meningkatkan kemampuan mengenal bentuk geometri. Melalui permainan cacaburange anak mampu meningkatkan kemampuan dalam mengenal bentuk geometri: anak dapat menyebutkan bentuk-bentuk geometri, meronce pola $\mathrm{ABCD}-\mathrm{ABCD}$ menggunakan bentuk geometri, menyusun bentuk geometri, dan dapat mengklasifikasikan bentuk geometri berdasarkan ukuran. Pemberian tindakan kegiatan bermain cacaburange merupakan salah satu bentuk penyajian kegiatan yang menyenangkan bagi anak untuk meningkatkan kemampuan dalam mengenal bentuk geometri.

\section{KESIMPULAN}

Berdasarkan tahapan yang telah dilakukan selama penelitian, sehingga dapat disimpulkan bahwa perolehan rata-rata kemampuan anak dalam mengenal bentuk geometri pada siklus I adalah 55,70 \% dan masing-masing anak belum mengalami peningkatan sesuai yang diharapkan. Ratarata kemampuan mengenal bentuk geometri pada siklus II adalah 84,66\%. Dari data tersebut dapat dikatakan bahwa presentase kemampuan geometri anak pada akhir siklus II mencapai prosentase $84 \%$. Sesuai dengan interpretasi hasil analisis bahwa penelitian ini dikatakan berhasil jika ada ketercapaian minimal 71\%, maka pada akhir siklus II ini penelitian dikatakan berhasil karena persentase keberhasilan yang didapat sebesar $84 \%$ melebihi batas minimal yang telah disepakati. Dengan demikian dapat disimpulkan bahwa permainan cacaburange dapat menngkatkan kemampuan anak dalam mengenal bentuk geometri.

Berdasarkan simpulan tersebut, maka dapat disampaikan beberapa saran sebagai rekomendasi hasil penelitian, diantaranya: Lembaga-lembaga pendidikan anak usiadini agar dapat mengembangkan strategi belajar mengajar yang sesuai dengan prinsip pendidikan bagi anak usia dini khususnya anak usia 4-5 tahun. Bagi guru, agar dapat memberikan kesempatan kepada anak untuk bermain dan belajar sesuai dengan minatnya sehingga anak merasa senang dan mempunyai minat 


\section{PEDAGOGIKA}

Volume 10 (Nomor 2) 2019

Hal. 95-100

terhadap kegiatan pembelajaran. Bagi anak, agar kegiatan belajar yang dilakukan menyenangkan dengan menggunakan berbagai macam media yang bervariatif. Bagi mahasiswa dan peneliti selanjutnya, agar mengembangkan aspek-aspek yang diteliti sehingga diperoleh hasil penelitian yang lebih optimal, permainan tradisional dapat dikembangkan untuk berbagai penelitian baik yang terkait dengan aspek kognitif dalam hal ini kemampuan geometri ataupun aspek-aspek perkembangan anak yang lainnya.

\section{REFERENCES}

Arikunto, S., Suhardjono, \& Supardi. (2007). penelitian tindakan kelas. Jakarta: Bumi Aksara.

Eliyawati, C. (2005). Pemilihan dan Pengembangan Sumber Belajar untuk Usia Dini. Jakarta: Departemen Pendidikan Nasional.

Lestari, K. (2011). Konsep Matematika. Jakarta: Departemen Pendidikan dan Kebudayaan.

Mansur. (2011). Pendidikan Anak Usia Dini (PAUD). Yogyakarta: Pustaka Belajar.

Mayesty, M. (1990). Creative Activitis For Young Children 4th ed: Play, development and creativity. New York: Delmark Publiser Inc.

N, S. Y. (2009). Konsep Dasar Pendidikan Anak Usia Dini. Jakarta: PT Indeks.

Rahmat, \& Taufiq, H. (2005). Peperenian Urang Sunda. Bandung: Kiblat.

Suharsimi, A. (2007). Prosedur Penelitian Suatu Pendekatan Praktek Edisi Revisi VI. Jakarta: Rineka Apta.

Sujiono, \& Dkk. (Metode Pengembangan Kognitif). 2008. Jakarta: Universitas Terbuka.

Tarigan. (2006). Pembelajaran Matematika Realistik. Jakarta: Departemen Pendidikan Nasioal.
Triharso, Agung. (2013). Permainan Kreatif dan Educatif untuk Anak Usia Dini. Yogyakarta: CV. Andi Offset. 